\title{
Energy Metabolism During Late Gestation and Lactation in Multiparous Sows in Relation to Backfat Thickness and the Interval from Weaning to First Oestrus
}

\author{
By F. Hultén, M. Neil, S.Einarsson and J. Håkansson
}

Department of Obstetrics and Gynaecology, Department of Animal Nutrition and Management and Department of Clinical Chemistry, Swedish University of Agricultural Sciences, Uppsala, Sweden.

\begin{abstract}
Hultén, F., M. Neil, S. Einarsson and J. Håkansson: Energy metabolism during late gestation and lactation in multiparous sows in relation to backfat thickness and the interval from weaning to first oestrus. Acta vet. scand., 1993, 34, 9-20. - Ten crossbred, fourth or fifth parity sows were divided into 2 groups - high (H) and low (L) - according to their backfat thickness 9 days before parturition. Body weight, backfat thickness and litter weight were recorded repeatedly during a 5 week lactation period. The length of the interval from weaning to first oestrus was also noted. All sows were fed a commercial diet (11.9 $\mathrm{MJ} / \mathrm{kg}, 14.5 \%$ crude protein). During gestation, daily food intake was $2.2 \mathrm{~kg} / \mathrm{sow}$, while during lactation it was $3.0 \mathrm{~kg} / \mathrm{sow}$ plus $0.4 \mathrm{~kg} /$ piglet.

Blood samples were drawn on day 9 before parturition and on days 2, 7, 14 and 21 of lactation. The samples were analysed to determine concentrations of glucose, urea nitrogen, creatinine, triglycerides, free fatty acids and beta-hydroxybutyric acid.

In both groups, concentrations of free fatty acids and urea nitrogen were low on day 9 before parturition while those of triglycerides were high, indicating anabolism regardless of backfat thickness.

During the first week of lactation, concentrations of free fatty acids increased in the $\mathrm{H}$ group but not in the L-group, and concentrations of urea nitrogen were higher in the $\mathrm{H}$ group. These differences, together with the greater loss of weight observed in the H-group, indicate that catabolism of maternal fat and protein depots was more pronounced in the H-group than in the L-group during this time. On day 14 of lactation, both groups showed equally low concentrations of free fatty acids, decreasing creatinine concentrations and stable triglyceride and urea nitrogen concentrations. Furthermore, weight loss during the second and third weeks of lactation was low in both groups. These facts, taken together, indicate that the catabolic rate was decreasing in both groups during this period. No differences in return to oestrus interval were noted between the groups.

The present study indicates that under a restricted feeding regime the catabolic rate during the first week of lactation is higher in sows with higher backfat thickness in late gestation.

As lactation progresses, a more balanced metabolism is achieved regardless of backfat thickness, which may tend to reduce differences in return to oestrous interval.
\end{abstract}

parturition; body composition; free fatty acids; urea nitrogen; progesterone.

\section{Introduction}

During mid gestation, when the metabolism of the well fed sow is anabolic, fat and protein are deposited in both maternal and foetal tissue (Close et al. 1985). During late gestation, pro- 
tein and energy accretion in maternal tissue decrease regardless of the food intake level. Consequently, a negative maternal energy balance can develop before farrowing in the poorly fed sow (Close et al. 1985). This metabolic change is reflected by decreasing insulin concentrations (Simoes Nunes et al. 1987) and increasing serum concentrations of free fatty acids (Ruiz et al. 1971), alanine (Simoes Nunes et al. 1987) and urea nitrogen (Ruiz et al. 1971), indicating that maternal fat and protein are being mobilized.

After parturition, suckling stimulates the release of prolactin and oxytocin from the maternal pituitary gland. In the rat these hormones have been found to promote the utilization of maternal stores of energy and protein for milk synthesis. Prolactin in the rat has been shown to induce an increase in the number of insulin receptors in mammary gland and a decrease in their number in maternal fat (Flint et al. 1981, Flint 1982), while oxytocin mobilizes glucose from maternal stores and contributes to its deposition in the mammary gland (Altszuler \& Hampshire 1981, Stock \& Uvnäs-Moberg 1985). In addition, suckling induces the secretion of glucagon (Algers et al. 1989), which promotes the release of maternal energy supplies through glycogenesis, through the breakdown of triglycerides in fat depots and by inhibiting hepatic fatty acid production (Stryer 1981). Although it is well established that the sudden shift to catabolism during early lactation in the bovine often results in hyperketonemia, no such change has been noted to occur in the sow (Sherer et al.1980).

The rate at which maternal fat depots are mobilized in the sow during lactation, reflected by a loss of weight and a decrease in backfat thickness, is influenced by body weight and backfat thickness at farrowing (Yang et al. 1989, Rojkittikhun et al. 1992), litter size (Sterning et al. 1990, Yang et al. 1989), litter weight gain (Sterning et al. 1990) and lactation feeding (John- ston et al. 1986, Yang et al. 1989), but the rate of maternal fat mobilization varies considerably between sows (Reese et al. 1984, Sterning et al. 1990).

A large degree of genetically determined variation in weight loss during the first lactation has been reported (Rydhmer et al. 1992).

Furthermore, differences in lipolytic capacity between genetically lean and fat breeds have been shown in vivo (Wood et al. 1977) and in vitro (Standal \& Vold 1973). This indicates that individual differences in energy metabolism might exist between equally nourished sows with the same performance during lactation (Rojkittikhun et al. 1992). It is well known that excessive fat loss during lactation delays the return to normal cyclic activity after weaning (Reese et al. 1984, Sterning et al. 1990).

Thus, it is of great importance to study the energy metabolism of sows during late gestation and lactation to receive further knowledge about the individual differences that seem to exist. The objectives of the present study were to study serum concentrations of certain energy and protein metabolites during late gestation and lactation in the sow, in relation to backfat thickness during late pregnancy and to changes in body weight during the first 3 weeks of lactation.

\section{Material and methods}

This study was performed with 11 fourth or fifth parity, crossbred Swedish Yorkshire $\mathrm{x}$ Swedish Landrace sows kept at a research station belonging to the Department of Animal Nutrition and Management.

During gestation the sows were kept indoors, with 3 or 4 sows in each pen. Three weeks before expected farrowing they were moved to individual farrowing pens, where they remained during the lactation period, which lasted 33-37 days. After weaning they were moved back to the gestation unit. 
Table 1. Composition of the sow diet.

\begin{tabular}{lc}
\hline Crude protein, \% & 14.5 \\
Lysine, \% & 0.65 \\
Methionine + cystine, \% & 0.50 \\
Methionine, \% & 0.25 \\
Threonine, \% & 0.48 \\
Ca, \% & 0.85 \\
P, \% & 0.70 \\
Metabolisable energy, MJ/kg & 11.9 \\
\hline
\end{tabular}

The animals were individually fed each day at $0800 \mathrm{~h}$ and $1500 \mathrm{~h}$. The composition of their diet is presented in Table 1.

Between day 1 of gestation and day 2 after farrowing, the sows were fed $2.2 \mathrm{~kg} /$ day. Thereafter the ration was gradually increased by 0.5 $\mathrm{kg} /$ day to a maximum of $3 \mathrm{~kg}+0.4 \mathrm{~kg}$ per piglet. After weaning the ration was decreased to $4 \mathrm{~kg} /$ day until mating or until 14 days after weaning, whichever came first. Food refusals was recorded on each blood sampling occasion, and the total amount of food refused during the study was recorded for each sow.

Sows were weighed on the day of farrowing once parturition had been completed, on days 7,14 and 21 of lactation, and within 2 days after weaning.

Ultrasonic measurements of backfat were made 9 days before expected farrowing, on day 21 of lactation, and within 2 days of weaning. Backfat thickness was measured at the last rib on both sides, approximately $8 \mathrm{~cm}$ from the middle of the back.

Sows were divided into 2 equally large groups according to their backfat thickness 9 days before parturition. Sows with a backfat thickness of $15 \mathrm{~mm}$ or more were assigned to the high (H) backfat thickness group, while those with a backfat thickness of less than $15 \mathrm{~mm}$ were assigned to the low (L) group.

Body temperature was recorded twice daily on day 9 before expected farrowing, on the day of farrowing and on the 2 following days, in order to detect agalactia post partum or any other infection.

After weaning, oestrous control was performed with a boar once daily, and the interval from weaning to first oestrus was recorded. If no oestrous signs were evident by day 11 after weaning, the concentration of plasma progesterone was determined in order to detect "silent oestrus".

Piglets were weighed at birth and at 3 weeks of age.

Blood samples were collected from the sow by puncturing the jugular vein on day 9 before expected farrowing (9.3 days before actual day of farrowing) and on days 2, 7, 14 and 21 of lactation. Samples were drawn 4 to $5 \mathrm{~h}$ after the morning feeding and were centrifuged immediately after having clotted. Serum was kept at $-20^{\circ} \mathrm{C}$ until the analyses were performed.

Serum concentrations of glucose, urea nitrogen, creatinine, triglycerides, free fatty acids and beta-hydroxybutyric acid were determined with a Cobas Mira multichannel analyzer (Roche, Basel). Standardized reagent kits (Roche kit nos. 071097-0, 07-1098-9, 07-1115-2, 07-1444-5, WIAKO kit no. 994-75409 and Sigma kit no. 310-A) were used. The serum concentration of glucose was determined by converting D-glucose to D-gluconate-6-phosphate, which produced a proportional amount of NADH that was measured spectrophotometrically at $340 \mathrm{~nm}$ (Bondar \& Mead 1974). Urea nitrogen was quantified with the urease-glutamic dehydrogenase reaction (Eisenweiner 1976), and creatinine with the Jaffe reaction at $500 \mathrm{~nm}$ (Fabiny \& Ertinghausen 1971). Triglycerides, free fatty acids and beta-hydroxybutyric acid were determined with enzymatic colorimetrical methods. The triglyceride concentration was determined according to its glycerol content (Megraw et al. 1979). The concentration of free fatty acids was determined by its ability to acylate coenzyme $\mathrm{A}$ in the presence of CoA-synthetase (Duncombe 1964), 
while the concentration of beta-hydroxybutyric acid was determined by oxidation it to acetoacetate which reduces a proportional amount of NAD to NADH (Custer et al. 1983). The plasma progesterone concentration was determined using a radioimmunoassay system (Bosu et al. 1976).

All analyses were performed at the Department of Clinical Chemistry, Swedish University of Agricultural Sciences, Uppsala, Sweden.

\section{Statistical analysis}

The statistical analysis was carried out with the SAS GLM-procedure (SAS Institute Inc. 1985). Changes in sow weight and backfat thick- ness were tested for effects of backfat thickness group (high or low). In the analysis of blood parameters the effect of day of sampling $(-9,2$, 7,14 or 21 days post partum), and backfat thickness of the sow 9 days ante partum (high or low) and the interaction of day and backfat thickness were tested.

\section{Results}

One sow showed agalactia post partum on the day after parturition, and was therefore excluded from the analysis. The other sows were all clinically healthy and had a normal appetite during the sampling period. Body temperatures ranged from 37.9 to $39.5^{\circ} \mathrm{C}$ during the day of parturi-

Table 2. Changes in live weight and backfat thickness of sows, litter size and weight during lactation and interval from weaning to first oestrus in the high and low backfat thickness groups (means with standard deviations)

\begin{tabular}{|c|c|c|c|}
\hline & \multicolumn{2}{|c|}{ Backfat thickness } & \multirow{2}{*}{$\begin{array}{c}\text { P-value, } \\
\text { effect of backfat } \\
\text { thickness }(\mathrm{H} \text { or } \mathrm{L})\end{array}$} \\
\hline & $\operatorname{High}(\mathrm{H})$ & Low $(\mathrm{L})$ & \\
\hline No of sows & 5 & 5 & \\
\hline \multicolumn{4}{|l|}{ Sow live weight (kg) } \\
\hline At farrowing & $226.8( \pm 21.3)$ & $200.4( \pm 22.8)$ & 0.10 \\
\hline Weight loss 1 st week of lact. & $14.0( \pm 5.0)$ & $4.2( \pm 3.2)^{1}$ & $0.01^{2}$ \\
\hline Weight loss 2nd week of lact. & $1.2( \pm 1.8)$ & $0.5( \pm 2.3)^{1}$ & 0.61 \\
\hline Weight loss 3rd week of lact. & $3.8( \pm 2.8)$ & $1.8( \pm 2.3)$ & 0.25 \\
\hline Weight loss from 3 weeks to weaning & $4.0( \pm 5.7)$ & $8.8( \pm 3.3)$ & 0.14 \\
\hline \multicolumn{4}{|l|}{ Backfat thickness (mm) } \\
\hline 9 days ante partum & $18.8( \pm 3.5)$ & $12.9( \pm 2.0)$ & 0.01 \\
\hline Loss 9 days a.p. to 3 rd week of lactation & $3.5( \pm 1.7)$ & $1.6( \pm 1.9)$ & 0.05 \\
\hline Loss 9 days a.p. to weaning & $4.4( \pm 2.0)$ & $1.9( \pm 1.9)$ & 0.08 \\
\hline \multicolumn{4}{|l|}{ Litter data } \\
\hline Litter size at birth & $13.6( \pm 2.1)$ & $11.6( \pm 2.7)$ & 0.26 \\
\hline - at 2 days post partum & $10.8( \pm 2.3)$ & $9.2( \pm 1.9)$ & 0.26 \\
\hline - at 3 weeks of age & $10.6( \pm 2.3)$ & $9.2( \pm 1.9)$ & 0.33 \\
\hline Total litter weight at birth $(\mathrm{kg})$ & $21.1( \pm 2.7)$ & $16.3( \pm 2.8)$ & 0.02 \\
\hline Litter weight gain during the first 3 weeks $(\mathrm{kg})$ & $47.3( \pm 4.3)$ & $41.5( \pm 6.4)$ & 0.24 \\
\hline Lengh of weaning to first oestrus interval (days) & $5.2( \pm 0.8)^{3}$ & $5.6( \pm 0.5)$ & 0.51 \\
\hline
\end{tabular}

${ }^{1}$ One sow missing

$2(\mathrm{p}<0.05)$ indicates statistically significant effects

3 One sow with silent oestrus excluded 
Table 3. Serum concentrations of energy and protein metabolites in pregnant and lactating sows with high or low backfat thickness (least squares means).

\begin{tabular}{|c|c|c|c|c|c|c|c|c|}
\hline & \multicolumn{5}{|c|}{ Day after parturition } & \multicolumn{3}{|c|}{$P$-value for the effect of } \\
\hline & -9 & 2 & 7 & 14 & 21 & Day & $\begin{array}{l}\text { Backfat } \\
\text { thickness } \\
(\mathrm{H} \text { or } \mathrm{L})\end{array}$ & $\begin{array}{c}\text { Day } \\
\text { Backfat }\end{array}$ \\
\hline Glucose (nmol/1) & $4.17^{\mathrm{a} 1}$ & $4.71^{b}$ & $5.45^{\mathrm{c}}$ & $5.33^{c}$ & $5.42^{\mathrm{c}}$ & $<0.001$ & 0.92 & 0.84 \\
\hline Urea $(\mathrm{nmol} / \mathrm{l})$ & $3.55^{\mathrm{a}}$ & $3.56^{\mathrm{a}}$ & $4.14^{\mathrm{a}}$ & $4.99^{b}$ & $5.14^{\mathrm{b}}$ & $<0.001$ & 0.02 & 0.54 \\
\hline Creatinine $(\mu \mathrm{mol} / \mathrm{l})$ & $175^{\mathrm{a}}$ & $165^{\mathrm{a}}$ & $165^{\mathrm{a}}$ & $145^{b}$ & $138^{b}$ & $<0.001$ & 0.39 & 0.81 \\
\hline Triglycerides $(\mu \mathrm{mol} / \mathrm{l})$ & $640^{\mathrm{a}}$ & $332^{\mathrm{b}}$ & $332^{b}$ & $275^{b}$ & $322^{\mathrm{b}}$ & $<0.001$ & 0.83 & 0.22 \\
\hline Free fatty acids $(\mu \mathrm{mol} / \mathrm{l})$ & $261^{\mathrm{a}}$ & $352^{a}$ & $277^{a}$ & $117^{b}$ & $87^{b}$ & $<0.001$ & 0.01 & 0.11 \\
\hline $\begin{array}{l}\text { Betahydroxybutyric } \\
\text { acid }(\mu \mathrm{mol} / \mathrm{l})\end{array}$ & $389^{\mathrm{a}}$ & $241^{b}$ & $248^{b}$ & $245^{b}$ & $243^{b}$ & $<0.001$ & 0.38 & 0.09 \\
\hline
\end{tabular}

${ }^{1}$ Figures followed by different letters differ significantly $(\mathrm{p}<0.05)$.

tion and the 2 following days. Two sows occasionally refused some of their daily food rations during the last 2 weeks of lactation. The total amount of food refused by these sows was 1 and 2 daily rations, respectively.

Changes in live weight and backfat thickness of the sows, litter size, litter weight and length of the interval from weaning to first oestrus are given for the $\mathrm{H}$ - and L-groups in Table 2.

Sow weight loss was greatest during the first week of lactation. This loss was most evident in the $\mathrm{H}$ group, amounting to $14.0 \mathrm{~kg}$ during the first week of lactation and a total of $16.6 \mathrm{~kg}$ during the first 3 weeks. The difference in weight loss between the 2 groups was significant during the first week $(\mathrm{p}<0.01)$. Weight loss was slightly higher in the L-group than in the $\mathrm{H}$-group during the last 2 weeks of lactation.

Backfat thickness decreased in both groups from 9 days before farrowing until day 21 of lactation, but the decrease was highest in the H-group. $(p<0.05)$. During the last 2 weeks of lactation there was only a slight decrease in backfat thickness, which was about the same in both groups. The number of piglets born, litter weight at birth and litter size on day 21 of lactation were higher in the H-group than in the L-group.
The interval from weaning to first oestrus (mean 5.4 days) did not differ significantly between the 2 groups. One sow in the H-group that showed silent oestrus was not included in the calculation of the mean interval.

Serum concentrations of the metabolites in the $\mathrm{H}$ and $\mathrm{L}$ groups are presented in Fig. 1. Results from the statistical analysis on the effects of day and backfat thickness are presented in Table 3. The concentration of glucose was low and equal in the 2 groups 9 days ante partum. By day 2 of lactation, it had risen in both groups $(\mathrm{p}<0.05)$, and a further rise was noted between day 2 and day $7(\mathrm{p}<0.05)$. Thereafter only minor changes occurred, as reflected by values on days 14 and 21 of lactation.

The concentration of urea nitrogen was similar in the 2 groups 9 days before parturition. In the L-group, a minor decrease had occurred by day 2 of lactation, whereafter there was a continuous increase during the first 3 weeks of lactation. In the H-group the urea nitrogen concentration rose continuously from 9 days before parturition until day 14 of lactation. A difference $(\mathrm{p}<0.05)$ was found in urea concentration between the groups, with higher values noted in the H-group. 

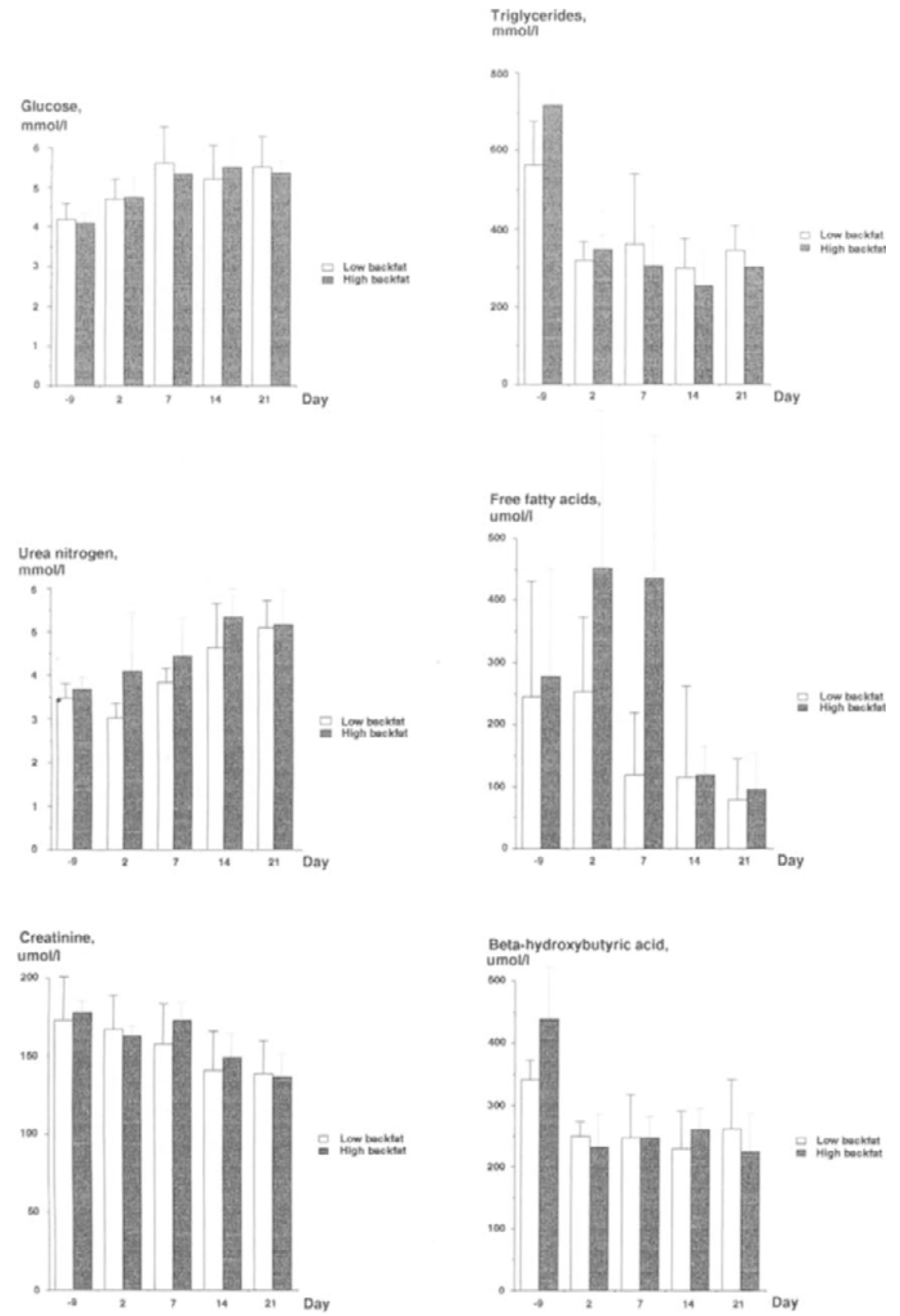

Figure 1. Serum concentration of some energy and protein metabolites in pregnant and lactating sows with high or low backfat thickness (means and standard deviations). 
In the L-group, the concentration of creatinine decreased continuously throughout the period, whereas in the H-group no decrease was noted until day 14 of lactation. Changes in creatinine concentration were significant over time but not between groups.

A significant decrease in the serum concentration of triglycerides was recorded in the $\mathrm{H}$ group between day 9 before parturition and day 2 of lactation. A further decrease, though not significant, occurred between day 2 and 14 of lactation. In the L-group, the decrease was significant between day 9 before parturition and day 2 of lactation, thereafter no changes occurred. The changes were significant over time but not between groups.

Serum concentrations of free fatty acids were similar in the 2 groups 9 days before parturition. By day 2 of lactation, the concentration had increased considerably in the $\mathrm{H}$-group. It remained stable until day 7 , but by day 14 a significant decrease had occurred, and the concentration was low on day 21.

In the L-group, the concentration of free fatty acids remained unchanged from day 9 before parturition until day 2 of lactation.

Between day 2 and 7 the concentration decreased sharply, whereafter it remained low and stable until day 21 of lactation. The changes were significant over time $(\mathrm{p}<0.01)$ and between groups $(\mathrm{p}<0.05)$, with higher concentrations in the $\mathrm{H}$ group.

Before parturition the concentration of betahydroxybutyric acid tended to be higher in the $\mathrm{H}$-group than in the L-group. By day 2 of lactation, concentrations in both groups had decreased and were equal. Thereafter they remained stable until day 21 of lactation.

\section{Discussion}

This study demonstrated that highly pregnant sows in the H-group were able to maintain their maternal fat reserves at higher levels than sows in the L-group even though the former had to nourish a larger number of foetuses while receiving the same food ration as the latter. During late gestation, the 2 groups had similar concentrations of free fatty acids, urea nitrogen and triglycerides, the former 2 being low and the latter high. These similarities suggest that the difference in backfat thickness was due to a greater predisposition to deposit fat in the $\mathrm{H}$-group during early and mid pregnancy rather than to a higher catabolic rate during late pregnancy in the L-group.

During the first week of lactation, catabolism was excessive in the $\mathrm{H}$-group, as reflected by high concentrations of free fatty acids, increasing urea nitrogen concentrations and pronounced weight loss.

Catabolism during the same period in the L-group was less pronounced. Similarly, it was found that during the first 10 days post partum, the energy balance of thin sows was less negative than that of sows in normal condition (de Lange et al. 1980).

As lactation proceeded concentrations of free fatty acids and creatinine decreased, while those of triglycerides stabilized in both groups, indicating that the metabolism was becoming more balanced. Further, only moderate loss of backfat was noted in both groups during the last 2 weeks of lactation. Consequently, the reason why no delay in return to normal cyclic activity was noted could have been that all sows were able to maintain maternal energy supplies at a sufficient level during late lactation. In previous studies the influence of weight loss and feeding level during lactation and backfat thickness at weaning on the length of the interval from weaning to first oestrus was found to be significant in primiparous sows but less evident in multiparous sows (Reese et al. 1982, Yang et al. 1989). Furthermore, the ratio between backfat change during lactation and body weight at parturition was 0.036 for parity 1 and between 
0.020 and 0.026 for parities 2 to 4 (Yang et al. 1989). These findings are in accordance with the present study and suggest that although multiparous sows lose weight and backfat during lactation, they are less prone to develop a negative balance severe enough to reduce the ability to show standing oestrus after weaning.

A considerable proportion (13-53\%) of the triglycerides passing through mammary circulation is excreted and incorporated into milk components during lactation (Linzell et al. 1969). Such incorporation might explain the marked decrease in triglyceride concentration observed at the onset of lactation in the present study. The decrease was more pronounced in the $\mathrm{H}$-group, despite their increasing food allowance and the excessive mobilization of maternal fat. A possible explanation might be an impaired ability to digestively adapt to an increase in the demand for triglycerides in the H-group, since elevated energy intake in a previous study led to an increase in triglyceride concentration (Ruiz et al. 1971).

Suckling induces an increase in serum concentration of gastrin while somatostatin concentration decreases (Uvnäs-Moberg et al. 1984). These changes indicate that an increase in digestive capacity occurs with onset of lactation.

The triglyceride concentrations were equal in the 2 groups before parturition, agreeing with previous comparisons made between lean and obese sows during pregnancy (Pond et al. 1983). A considerable amount of glycogen is deposited in the foetuses during the last week of gestation (Hakkarainen 1975). Consequently, a decrease in the concentration of triglycerides in the sow might even occur before parturition, when energy metabolites are shunted to the foetal circulation.

In accordance with the results of the present study, a decrease in the concentration of free fatty acids was recorded in primiparous sows during ear- ly lactation (Ruiz et al. 1971). Concentrations of free fatty acids in primiparous sows that showed high weight loss were low still at the fifth week of lactation (Hultén, unpublished results). The uptake of free fatty acids by the lactating mammary gland is low (Linzell et al. 1969, Spincer et al. 1969), suggesting that mobilized maternal fat is metabolized before being incorporated into milk components.

Despite the negative energy balance during early lactation, which was most evident in the H-group, low concentrations of beta-hydroxy butyric acid were noted. In earlier studies, the concentration of beta-hydroxybutyric acid during gestation and lactation in primiparous sows increased or remained unchanged (Ruiz et al. 1971, von Maryke et al. 1976, Sherer 1980). The results of studies on the fat metabolism in piglet liver cells suggest that species specific resistance to ketone body formation exists (Pégorier et al. 1983). This suggestion is supported by the observation that even in starved pigs the increase in ketone body formation was only moderate (Bengtsson et al. 1969, Gentz et al. 1970). The fact that plasma concentrations of glucose increased after parturition in both groups agrees with earlier studies (Ruiz et al. 1971, Nachreiner \& Ginther 1972a,b, Pond et al. 1983).

Initially, this increase might be due to a rise in the cortisol concentration at parturition (Molokwu et al. 1973), while suckling-induced releases of oxytocin (Forsling et al. 1979), gastrin (UvnäsMoberg et al. 1984) and glucagon (Eriksson et al. 1987, Algers et al. 1989) might account for the increase as lactation proceeds.

Nitrogen retention has been shown to occur during the week before parturition in both poorly fed, thin sows and in adequately fed sows in normal condition (de Lange et al. 1980). Nitrogen is mainly deposited as foetal protein during late pregnancy and deposition is much lower in the maternal tissue of pregnant animals than in nonpregnant animals (Close et al. 1985). 
Since urea nitrogen is the end product of nitrogen metabolism in terrestrial vertebrates (Kaneko 1989), increasing serum concentrations of urea are indicative of protein catabolism in animals whose dietary intake has not changed.

In the present study, concentrations of urea nitrogen were low in both groups 9 days before parturition, which supports previous reports of protein anabolism during late gestation (Close et al. 1985). The increase in concentrations noted during early lactation in both groups correlated well with the increase in food intake, but although the level of food intake was still unchanged at day 2 of lactation, the urea concentration had already started to increase in the $\mathrm{H}$-group at this time. Furthermore, urea concentrations were significantly higher in the $\mathrm{H}$ group than in the L-group throughout the study. The fact that weight loss was initially more pronounced in the H-group suggests that the higher urea concentration in sows in this group was due to their higher rate of maternal protein mobilization. Thin, multiparous sows have been shown to lose less nitrogen during the first week of lactation than normal sows fed the same ration (de Lange et al. 1980).

Creatinine is the end product of muscle catabolism and increases in connection with the wasting of muscle tissue (Wallach et al.1978). The fact that the creatinine concentration in the present study was already high before parturition and that the urea concentration was low at the same time suggests that maternal protein was converted into foetal protein. The high concentration of creatinine at the onset of lactation together with the increase in the urea concentration and the considerable loss of weight suggest that muscle protein was mobilized and that protein metabolites were lost. The decline in the concentration of creatinine over the 3-week period and the fact that weight loss during the second and third weeks of lactation was only moderate indicate that protein catabolism decreased and that the demand for precursors needed for milk synthesis was more adequately covered by ingested nutrients. The tendency for the decrease in creatinine concentration to be delayed in the H-group might have been due to the more pronounced weight loss in this group during the first week of lactation.

The findings of the present study indicate that with the feeding regime used the metabolism is anabolic in the multiparous sow during late gestation, but with the onset of lactation an immediate shift to catabolism occurs. Sows with higher backfat thickness at parturition mobilize maternal depots at a higher rate during the first week of lactation than sows with lower backfat thickness. The metabolism stabilizes in both groups as lactation progresses, whereby differences in maternal fat loss gradually decrease and consequently a delay in return to oestrus interval is inhibited.

\section{Acknowledgements}

This work was supported by grants from the Swedish Council for Forestry and Agricultural Research, the Farmer's Research Council for Information and Development and the Swedish University of Agricultural Sciences.

The authors wish to thank Prof. Gösta Bengtsson for inspiring discussions, Dr Lennart Thunberg for valuable advise and Carola Janson for excellent technical assistance .

\section{References}

Algers B, Madej A, Rojanasthien S, Uvnäs-Moberg K: Quantitative relationship between suckling-induced teat stimulation and the release of prolactin, gastrin, somatostatin, insulin, glucagon and VIP in sows. In: Algers B. (Ph. D. Thesis): Vocal and tactile communication during suckling in pigs. Aspects on function and effects of continuous noise. Dept of Anim. Hyg., Swed. Univ. of Agric. Sci., Report 25 1989.

Altszuler N, Hampshire J: Oxytocin fusion increases plasma insulin and glucagon levels and glucose production and uptake in the normal dog. Diabetes 1981, 30, 112-114. 
Bengtsson G, Gentz J, Hakkarainen J, Hellström R, Persson B: Plasma levels of FFA, glycerol, beta-hydroxybutyrate and blood glucose during the postnatal development of the pig. J. Nutrition. 1969, 97, 311-315.

Bondar RJ L, Mead D C: Evaluation of glucose-6 phosphate dehydrogenase from Leuconostoc mesenteroides in the hexokinase method for determining glucose in serum. Clin. Chem. 1974, 20, 586-590.

Bosu W T K, Edqvist L-E, Lindberg P, Martinsson K, Johansson $E D B$ : The effect of various dosages of lynestrenol on plasma levels of oestrogen and progesterone during the menstrual cycle in rhesus monkey. Contraception. 1976, 13, 677-684.

Close W H, Noblet J, Heavens R P: Studies on the energy metabolism of pregnant sow. 2 . The partition and utilization of metabolizable energy intake in pregnant and non-pregnant animals. Br. J. Nutr. 1985, 53, 267-279.

Custer EM, Myers JK, Proffenbarger PL, Schoen I: The storage stability of 3-hydroxybutyrate in serum and plasma and whole blood. Amer. J. clin. Path. 1983, 80, 375.

De Lange PGB, van Kempen GJM, Klaver J, Verstegen $M W A$ : Effect of condition of sows on energy balances during 7 days before and 7 days after parturition. J. Anim. Sci. 1980, 50, 5, 886-891.

Duncombe WG: The colorimetric determination of nonesterified fatty acids in plasma. Clin Chim. Acta. 1964, 9, 122-125.

Eisenweiner HG: Kinetische Bestimmung des Harnstoffes mit dem LKB-system. J. Clin. Chem. Clin. Biochem. 1976, 14, 261-264.

Eriksson M, Einarsson S, Kunavongkrit A, UvnäsMoberg K: Increase of insulin and decrease of glucagon levels in response to total and fractionated weaning in sows. Acta physiol. scand. 1987, 131, 387-390.

Fabiny DL, Ertinghausen G: Automated reaction rate method for determination of serum creatinine with the Centri Chem. Clin. Chem. 1971, 17, 696700.

Flint DJ: Regulation of insulin receptors by prolactin in lactating rat mammary gland. J. Endocr. 1982, 93, 279-285.

Flint DJ, Clegg RA, Vernon RG: Prolactin and the regulation of adipose tissue metabolism during lactation in rats. J. Molec. Endocrinol. 1981, 22, 265275.

Forsling ML, Taverne MAM, Pravizi F, Elsaesser F, Smidt $D$, Ellendorff F: Plasma oxytocin and steroid concentrations during late pregnancy, parturi- tion and lactation in the miniature pig. J. Endocr. 1979, 82, 61-69.

Gentz J, Bengtsson G, Hakkarainen J, Hellström R, Persson $B$ : Metabolic effects of starvation during neonatal period in the pig. Amer. J. Phys. 1970, 218, 662-668.

Hakkarainen J: Developmental changes of protein, RNA, DNA, lipids and glycogen in the liver, skeletal muscle and brain of the piglet. $\mathrm{Ph}$. D. Thesis. Dept. of animal nutrition and management, Swed. Univ. of Agric. Sci. Acta vet. scand. 1975. Suppl. 59.

Johnston LJ, Orr JrDE, Tribble LF, Clark JR: Effect of lactation and rebreeding phase energy intake on primiparous and multiparous sow performance. $\mathbf{J}$. Anim. Sci. 1986, 63, 804-814.

Kaneko JJ: In: Clinical biochemistry of domestic animals. 1989. 4th Edt. Academic Press Inc.

Linzell JL, Mepham TB: Mammary metabolism in lactating sows: arteriovenous differences of milk precursors and the mammary metabolism of (14C)glucose and (14C)acetate. Br. J. Nutr. 1969, 23, 319-332.

Maryke Von, Dudzus, Uecker E: Untersuchungen zum Kohlenhydratstoffwechsel hochtragender Sauen unter besonderer Berücksichtigung der Geburtsmasse des Frekels. (Studies into carbohydrate metabolism of sows in advanced pregnancy, with special reference to piglet birth weight). Mh. Vet.-Med. 1976, 31, 23, 906-910.

Megraw EM, Dunn DE, Biggs HG: Manual and continuousflow colorimetry of triacylglycerols by a fully enzymatic method. Clin. Chem. 1979, 25, 273-278.

Molokwu ECI, Wagner W C: Endocrine physiology of the puerperal sow. J. Anim. Sci. 1973, 33, 1158-1163.

Nachreiner RF, Ginther OJ: Gestational and periparturient periods of sows: serum chemical and hematologic changes during gestation. Amer. J. vet. Res. 1972a, 33, 2215-2219.

Nachreiner RF, Ginther OJ: Gestational and periparturient periods of sows: serum chemical, hematologic and clinical changes during the periparturient period. Am. J. Vet. Res. 1972b, 33, 2233-2238.

Pégorier JP, Duée PH, Girard J, Peret J: Metabolic fate of non-esterified fatty acids in isolated hepatocytes from newborn and young pigs. Biochem. J. 1983, 212, 93-97.

Pond WG, Yen JT, Mersmann HJ, Yen LH: Effect of gestation diet intake on plasma lipids and progeny birth and weaning weights of genetically lean, obese and contemporary swine. J. Nutr. 1983, 113, 436-446. 
Reese DE, Moser BD, Peo ER Jr, Lewis AJ: Influence of energy intake during lactation on the interval from weaning to first estrus in sows. J. Anim. Sci. 1982, 55, 590-598.

Reese DE, Peo JrER, Lewis AJ: Relationship of lactation energy intake and occurrence of postweaning estrus to body and backfat composition in sows. J. Anim. Sci. 1984, 58, 1236-1244.

Rojkittikhun T, Einarsson S, Edqvist L-E, UvnäsMoberg K, Lundeheim N: Relationship between lactation-associated body weight loss, levels of metabolic and reproductive hormones and weaning-to-oestrous interval in primiparous sows. 1992, J. Vet. Med. A. 1992, 39, 426-432.

Ruiz ME, Ewan RC, Speer VC: Serum metabolites of pregnant and hysterectomized gilts fed two levels of energy. J. Anim. Sci. 1971, 32, 1153-1159.

Rydhmer L, Johansson K, Stern S, Eliasson-Selling L: A genetic study of pubertal age, litter traits, weight loss during lactation and relation to growth and leanness in gilts. Acta Agric. Scand. 1992, 42, 211219.

SAS Institute Inc.: SAS stat TM User's Guide. Ed. 5 Cary. NC 1985.

Sherer von B, Blume J, Thieman KG: Untersuchungen zur Ketose beim Schwein. (Studies into ketosis in swine) Mh. Vet.-Med. 1980, 35, 855-857.

Simoes Nunes C, Duée PH, Pégorier JP, Rérat A: Effect of feed intake level in late gestation on arterial blood concentrations of energy substrates, insulin and glucagon in the chronically catheterized gilt. Reprod. Nutr. Dévelop. 1987, 27, 77-87.

Spincer J, Rook JAF, Towers KG: The uptake of plasma constituents by the mammary gland of the sow. Biochem. J. 1969, 111, 727-732.

Standal N, Vold E: Lipid mobilization in pigs selected for leanness or fatness. Anim. Prod. 1973, 16, 37 42.

Sterning M, Rydhmer L, Eliasson L, Einarsson S, Andersson $K$ : A study on primiparous sows of the ability to show standing oestrus and to ovulate after weaning. Influences of loss of body weight and backfat during lactation and of litter size, litter weight gain and season. Acta vet. scand. 1990,31, 227-236.

Stock S, Uvnäs-Moberg K: Oxytocin infusions increase plasma levels of insulin and VIP but not of gastrin in consious dogs. Acta Physiol. Scand. 1985, 125, 205-210.

Stryer L: Biochemistry. (2nd Ed.). WH Freeman \& Co. San Francisco 1981. 549-550.

Uvnäs-Moberg K, Eriksson M, Blomquist LE, Kunavongkrit $A$, Einarsson $S$ : Influence of suckling and feeding on insulin, gastrin, somatostatin and VIP levels in peripheral venous blood of lactating sows. Acta Physiol. Scand. 1984, 121, 31-38.

Wallach J: Interpretation of diagnostic tests. (3rd. Ed.) Little, Brown \& Co., Boston, MA. 1978.

Wood JD, Gregory NG, Hall GM, Lister D: Fat mobilization in Pietrain and Large White pigs. Br. J. Nutr. 1977, 37, 167-186.

Yang H, Eastham PR, Phillips P, Whittemore CT: Reproductive performance, body weight and body condition of breeding sows with differing body fatness at parturition, differing nutrition during lactation and differing litter size. Anim. Prod. 1989, $48,181-201$.

\section{Sammanfattning}

En studie av energiomsättningen hos sugga under sen dräktighet och laktation, i relation till späcktjocklek och intervall mellan avvänjning och första brunst.

Tio korsningssuggor i fjärde eller femte dräktighetsperiod uppdelades i 2 grupper - hög $(\mathrm{H})$ och låg $(\mathrm{L})$ - med avseende på deras späcktjocklek 9 dagar innan grisningen.

Kroppsvikt, späcktjocklek och kullvikt registrerades under en 5 veckor lång laktationsperiod. Intervallet mellan avvänjning och första brunst noterades.

Samtliga suggor utfodrades med ett kommersiellt suggfoder (11,9 MJ/kg, 14,5\% råprotein). Under dräktighetsperioden var den dagliga fodernormen $2,2 \mathrm{~kg} /$ sugga och under laktationen $3,0 \mathrm{~kg} / \mathrm{sugga}+0,4$ $\mathrm{kg} / \mathrm{smågris.}$

Blodprover togs 9 dagar före grisningen samt dag 2, 7, 14 och 21 i laktationen. Proverna analyserades avseende serumkoncentration av glukos, urea-kväve, kreatinin, triglycerider, fria fettsyror och beta-hydroxysmörsyra. Dag 9 före grisningen noterades låga koncentrationer av fria fettsyror och urea-kväve samt höga koncentrationer av triglycerider $\mathrm{i}$ båda grupperna, vilket indikerar anabol metabolism. Stigande koncentration av fria fettsyror under första laktationsveckan i Hgruppen, men ej i L-gruppen, höga koncentrationer av urea-kväve under tidig laktation i H-gruppen samt större viktförlust indikerar mer uttalad katabolism i $\mathrm{H}$-gruppen än i L-gruppen under tidig laktation. Låga koncentrationer av fria fettsyror i båda grupperna efter första laktationsveckan. sjunkande kreatininkoncentrationer och stabila koncentrationer av urea-kväve och triglycerider i båda grupperna under andra och tredje laktationsveckan indikerar minskad katabolism. Ingen skillnad i intervallet mellan avvänjning och första 
brunst noterades mellan grupperna.

Denna studie indikerar att vid restriktiv utfodring är metabolismen mer katabol under första laktationsveckan hos suggor med högre späcktjocklek i sen dräktighet.
Längre fram i laktationen uppnås en mer balanserad metabolism, oberoende av späcktjockleken, vilket kan motverka att skillnader $\mathrm{i}$ intervallet mellan avvänjning och första brunst uppstår.

(Received September 21, 1992; accepted September 30, 1992).

Reprints may be requested from: F. Hultén, Department of Obstetrics and Gynaecology, P. O. Box 7039, Faculty of Veterinary Medicine, Swedish University of Agricultural Sciences, S-750 07 Uppsala, Sweden. 